\title{
Pan-hysterectomy for Closed Pyometra in a Dog
}

\author{
Dayamon David Mathew ${ }^{1}$, Vinod Kumar ${ }^{2}$, Rahul Kumar Udehiya ${ }^{1}$, Naresh Kumar Singh ${ }^{1, *}$
}

\begin{abstract}
Pyometra is infection of the uterus with presence of pus inside the uterus. A 2.5 years old intact female dog weighing $25 \mathrm{kgs}$ was presented with a history of anorexia and pain on palpation of thoraco-abdominal region. On physical examination, the abdomen was tensed. Lateral abdominal radiography and ultrasonography was performed and diagnosed as pyometra which is a closed-cervix type. Pan-hysterectomy was performed under general anesthesia as treatment to save the animal. Post-operatively the animal was on antibiotics and anti-inflammatory drugs for 5 days and kept on fluid therapy for 3 days. The pet had an uneventful recovery.

Key words: Hysterectomy, Pan-hysterectomy, Closed pyometra, Open pyometra, Dog.
\end{abstract}

\section{INTRODUCTION}

Infection of uterus is called as pyometra and this may occur in dogs and cats. Canine pyometra is a common affection of the uterus seen usually in intact, sexually mature bitches with signs specific to the reproductive system along with systemic signs. ${ }^{1}$ Usually, pus may be filled within the uterus. The hormones, progesterone and estrogen and their receptors have a role in the development of pyometra and the infection is triggered by bacterial involvement. This usually occurs one to two months following estrus due to elevated progesterone level. ${ }^{2}$ Pyometra can be either closed pyometra or open pyometra. Severe pyometra sometimes leads to fatality due to systemic infection and infertility. Pyometra can be medically managed when the condition is not life threatening and when it is an open-cervix type. This may include use of PGF2alpha, Prostaglandins, progesterone receptor blockers like aglepristone, broad spectrum antibiotics, prolactin inhibitors like bromocriptine or cabergoline. Ovario-hysterectomy is considered to be the most effective method to treat pyometra. ${ }^{3,4}$

\section{Case history and clinical signs}

An intact female cross bred dog, aged two and a half years, weighing $25 \mathrm{kgs}$, was presented to Teaching Veterinary Clinical Complex, Faculty of Veterinary and Animal Sciences, Banaras Hindu University, Mirzapur with a history of anorexia and pain on palpation of thoraco-abdominal region and referred to the Department of Veterinary Surgery and Radiology. The pet had a temperature of $103.4^{\circ} \mathrm{F}$. On auscultation, the pet had a heart rate of 55 beats/ minute and respiratory rate was 28 respirations/ minute. Blood sampling was done for total count, differential count, hemoglobin, Red Blood Cells, Packed Cell Volume, Mean Corpuscular Hemoglobin $(\mathrm{MCH})$ and Mean Corpuscular

Cite this article : Mathew DD, Kumar V, Udehiya RK, Singh NK. Pan-hysterectomy for Closed Pyometra in a Dog. BEMS Reports. 2021;7(1):4-5.
Hemoglobin Concentration (MCHC) (Table 1). On physical examination, the abdomen was tensed and on palpation pet showed pain. Lateral radiography of the abdomen was performed and it was suggestive of distended uterus in the caudo-ventral abdominal region (Figure 1). On ultrasonography, presence of fluid filled sac was observed in the abdominal cavity. The animal had no history of vaginal leakage of fluid. The case was diagnosed as closed pyometra and decided to perform Pan-hysterectomy.

\section{Treatment}

The animal was premedicated with atropine $(0.045 \mathrm{mg} / \mathrm{kg} \mathrm{b}$. wt) and diazepam (1mg/kg b. wt) administered intra-muscularly. Preemptive analgesic (Meloxicam at a dose of $0.2 \mathrm{mg} / \mathrm{kg} \mathrm{b}$. wt) and antibiotic (Ceftriaxone at a dose of $20 \mathrm{mg} / \mathrm{kg} \mathrm{b}$. wt) was administered intra-venously. The animal was pre-surgically hydrated with Ringer's lactate solution and continued till recovery. The animal was prepared on the mid-ventral aspect. Anesthesia was induced with a mixture of ketamine $(5 \mathrm{mg} / \mathrm{kg} \mathrm{b}$. wt.) and diazepam $(0.5 \mathrm{mg} / \mathrm{kg})$ administered intramuscularly and maintained with isoflurane. Laparotomy incision was made on the linea alba to approach the abdominal cavity. The uterus was exteriorized and packed the cavity to prevent spillage of contents into the abdominal cavity. The ovarian end was clamped and the vessels were transfixed using chromic catgut no. 2-0, severed the vessels on one side and separated uterus and the procedure was repeated on the other side to remove the uterus and ovaries. The vessels at the cervical end were also transfixed and severed it to separate the pus-filled uterus (Figure 2). The abdominal incision was closed using polyglactin-910 and the skin was closed by simple interrupted sutures using Nylon sutures.

\section{Dayamon David Mathew ${ }^{1}$, Vinod Kumar², Rahul Kumar Udehiya ${ }^{1}$, Naresh Kumar Singh ${ }^{1, *}$ \\ ${ }^{1}$ Department of Veterinary Surgery and Radiology, Faculty of Veterinary and Animal Science, RGSC, Banaras Hindu University, Barkachha, Mirzapur, Uttar Pradesh, INDIA. \\ ${ }^{2}$ Teaching Veterinary Clinical Complex, Faculty of Veterinary and Animal Sci- ence, RGSC, Banaras Hindu University, Barkachha, Mirzapur, Uttar Pradesh, INDIA.}

\section{*Correspondence}

Dr. Naresh Kumar Singh, Ph.D

Department of Veterinary Surgery and Radiology, Faculty of Veterinary and Animal Sciences, Institute of Agricultural Sciences, Rajiv Gandhi South Campus, Banaras Hindu University, Barkachha, Mirzapur-231001, Uttar Pradesh, INDIA.

Phone no: +919554786939

E-mail: naresh2101@gmail.com

History

- Submission Date: 01-12-2020;

- Review completed: 08-12-2020

- Accepted Date: 11-12-2020.

DOI : 10.5530/bems.7.1.2

Article Available online

http://www.bemsreports.org

Copyright

(C) 2021 Phcog.Net. This is an openaccess article distributed under the terms of the Creative Commons Attribution 4.0 International license. 
Table 1: Table showing the blood values.

\begin{tabular}{ccc} 
SI. no. & Parameter & Value \\
\hline 1 & Total count & 39,200 cells $/$ microL \\
2 & Differential count $(\mathrm{N}, \mathrm{L}, \mathrm{M})$ & $85 \%, 8 \%$ and $7 \%$ \\
3 & Haemoglobin & $8.7 \mathrm{~g} \%$ \\
4 & $\mathrm{RBC}$ & 4.82 \\
5 & $\mathrm{PCV}$ & 59 \\
6 & $\mathrm{MCH}$ & 18 \\
7 & $\mathrm{MCHC}$ & $31 \mathrm{~g} \%$ \\
\hline
\end{tabular}

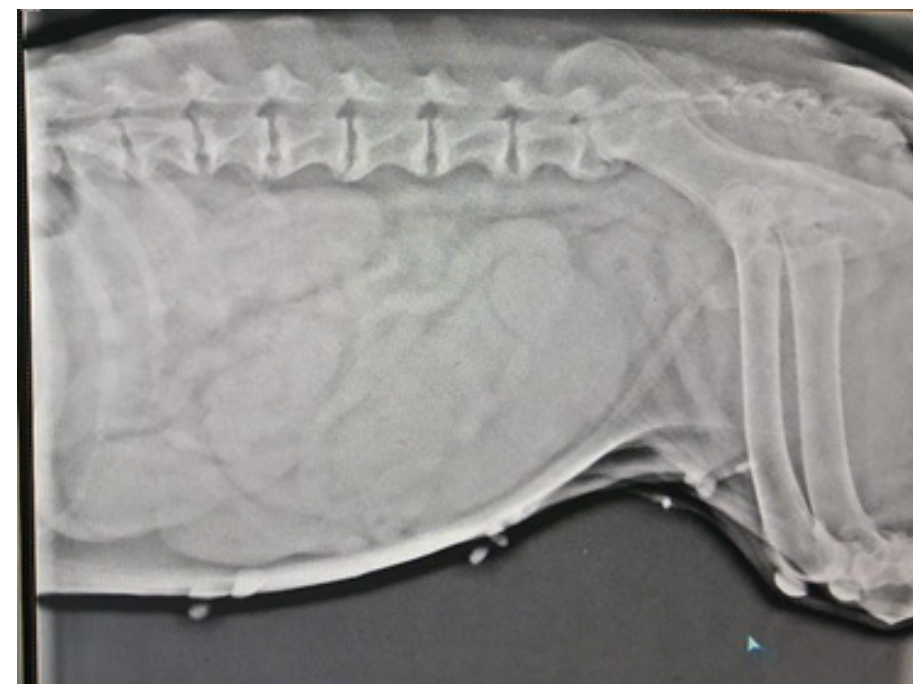

Figure 1: Lateral abdominal radiograph showing presence of fluid filled enlarged uterus.

Post-operatively the pet was kept on inj. Ceftriaxone and inj. Meloxicam for 5 days along with ranitidine and an oral multivitamin and was on fluids for 3 days. The sutures were removed on $10^{\text {th }}$ post-operative day after ascertaining the healing. The animal had an uneventful recovery.

\section{DISCUSSION}

Pyometra can be defined as pathological condition of uterus in which there is accumulation of purulent semisolid-liquid substance inside the uterus of intact bitches, generally during post-progesterone dominant phase of estrous cycle. ${ }^{1}$ Pyometra occur commonly in older dogs and it may occur in young to middle aged dogs and the most common age being 7.5 years with regular and repeated estrous cycle. ${ }^{4}$ Pyometra is often result of hormonal changes in the reproductive tract. Following oestrus, progesterone levels remain elevated for eight to ten weeks and thicken the lining of the uterus in preparation for pregnancy. If pregnancy does not occur for several oestrus cycles, the lining continues to increase in thickness until cysts form within it. The thickened cystic lining secretes fluids that create an ideal environment in which bacteria can grow. High progesterone levels inhibit the ability of the muscles in the wall of the uterus to contract.Pyometra usually occurs during luteal phase of estrous cycle, when progesterone level increases, which causes an increased endometrial gland secretion, increased endometrial proliferation, reduced myometrial contraction and closure of cervix. ${ }^{5}$ Pyometra in canines can be classified according to the status of cervix as open and closed cervix pyometra, in which the most serious and

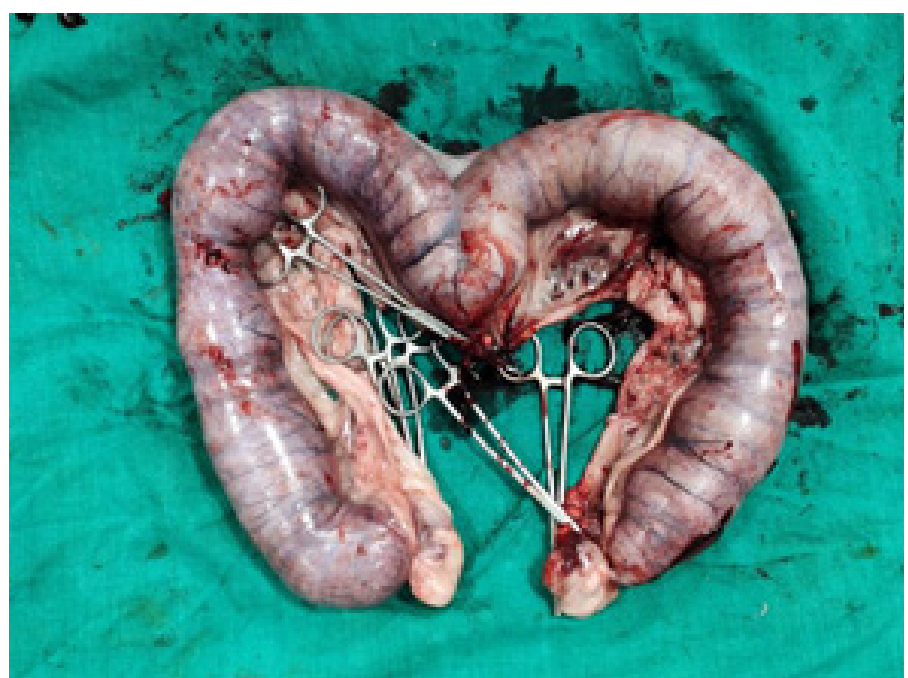

Figure 2: Pus filled uterus.

emergency condition is the closed-cervix pyometra, which requires surgical intervention to prevent sepsis and death. ${ }^{6}$ Intravenous fluids are often needed before and after surgery to control infection and for maintaining fluid balance. Antibiotics and anti-inflammatory drugs are also usually required for a period of time after surgery.

\section{CONCLUSION}

The paper reports the successful management of closed pyometra by performing pan-hysterectomy in a dog.

\section{ACKNOWLEDGEMENT}

The authors acknowledge Banaras Hindu University for providing all facilities to conduct the study.

\section{ABBREVIATIONS}

PGF2Alpha: Prostaglandin F2alpha; kgs: kilograms; ${ }^{\circ} \mathbf{F}$ : Degree Fahrenheit; MCH: Mean Corpuscular Hemoglobin; MCHC: Mean Corpuscular Hemoglobin Concentration; mg/kg: milligram per kilogram; b. wt.: body weight; RBC: Red Blood Cell; PCV: Packed Cell Volume.

\section{SUMMARY}

The paper describes about a successful surgical management of closed pyometra in an intact cross bred female dog.

\section{REFERENCES}

1. Kumar A, Saxena A. Canine pyometra: Current perspectives on causes and management: A review. Indian J Vet Sci Biotech. 2018;14(1):52-6.

2. Nelson RW, Feldman. Pyometra. Vet Clin North Am Small Anim Pract 1986;16:561-76

3. Feldman EC, Nelson RW. Cystic endometrial hyperplasia/pyometra complex in canine and feline endocrinology and reproduction. In Canine and feline endocrinology and reproduction. Ed Kersey, R and LeMelledo D. $3^{\text {rd }}$ edn W. B. Saunders Company. USA. 2004;847-60.

4. Johnston SD, Kustritz MVR, Olson PNS. Disorders of the canine uterus and uterine tubes (oviducts). Canine and Feline Theriogenology. W.B. Saunders. $2001 ; 206-24$.

5. Hardie EM. Life-threatening bacterial infection. Compend Contin Educ Pract Vet. 1995;17(6):763-78

6. Smith FO. Canine pyometra. Theriogenology. 2006;66(3):610-2 